\title{
In-situ measurements of atmospheric hydrofluorocarbons (HFCs) and perfluorocarbons (PFCs) at the Shangdianzi regional background station, China
}

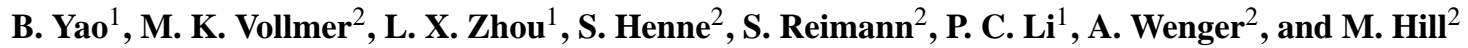 \\ ${ }^{1}$ Key Laboratory for Atmospheric Chemistry, Chinese Academy of Meteorological Sciences, China Meteorological \\ Administration, Beijing, China \\ ${ }^{2}$ Empa, Swiss Federal Laboratories for Material Science and Technology, Laboratory for Air Pollution and Environmental \\ Technology, Dübendorf, Switzerland
}

Correspondence to: L. X. Zhou (zhoulx@cams.cma.gov.cn, zhoulx2007@gmail.com)

Received: 1 April 2012 - Published in Atmos. Chem. Phys. Discuss.: 2 May 2012

Revised: 29 September 2012 - Accepted: 16 October 2012 - Published: 5 November 2012

\begin{abstract}
Atmospheric hydrofluorocarbons (HFCs) and perfluorocarbons (PFCs) were measured in-situ at the Shangdianzi (SDZ) Global Atmosphere Watch (GAW) regional background station, China, from May 2010 to May 2011. The time series for five HFCs and three PFCs showed occasionally high-concentration events while background conditions occurred for $36 \%$ (HFC-32) to $83 \%$ (PFC-218) of all measurements. The mean mixing ratios during background conditions were $24.5 \mathrm{ppt}$ (parts per trillion, $10^{-12}$, molar) for HFC-23, $5.86 \mathrm{ppt}$ for HFC-32, $9.97 \mathrm{ppt}$ for HFC-125, $66.0 \mathrm{ppt}$ for HFC-134a, $9.77 \mathrm{ppt}$ for HFC-152a, $79.1 \mathrm{ppt}$ for $\mathrm{CF}_{4}, 4.22 \mathrm{ppt}$ for PFC-116, and $0.56 \mathrm{ppt}$ for PFC-218. The background mixing ratios for the compounds at SDZ are consistent with those obtained at mid to high latitude sites in the Northern Hemisphere. North-easterly winds were associated with negative contributions to atmospheric HFC and PFC loadings (mixing ratio anomalies weighted by time associated with winds in a given sector), whereas southwesterly advection (urban sector) showed positive loadings. Chinese emissions estimated by a tracer ratio method using carbon monoxide as tracer were $3.6 \pm 3.2 \mathrm{kt} \mathrm{yr}^{-1}$ for HFC-23, $4.3 \pm 3.6 \mathrm{kt} \mathrm{yr}^{-1}$ for HFC-32, $2.7 \pm 2.3 \mathrm{kt} \mathrm{yr}^{-1}$ for HFC-125, $6.0 \pm 5.6 \mathrm{kt} \mathrm{yr}^{-1}$ for HFC-134a, $2.0 \pm 1.8 \mathrm{kt} \mathrm{yr}^{-1}$ for HFC-152a, $2.4 \pm 2.1 \mathrm{kt} \mathrm{yr}^{-1}$ for $\mathrm{CF}_{4}, 0.27 \pm 0.26 \mathrm{kt} \mathrm{yr}^{-1}$ for PFC-116, and $0.061 \pm 0.095 \mathrm{kt} \mathrm{yr}^{-1}$ for PFC-218. The lower HFC-23 emissions compared to earlier studies may be a result of the HFC-23 abatement measures taken as part of Clean Development Mechanism (CDM) projects that started in 2005 .
\end{abstract}

\section{Introduction}

Hydrofluorocarbons (HFCs) and perfluorocarbons (PFCs) are greenhouse gases with global-warming potential (GWP) values for time horizon of $100 \mathrm{yr}$ ranging from 140 to 11700 (IPCC, 2007) and they are included in the Kyoto Protocol. Most HFCs are used in refrigeration, air conditioning, in aerosol spray cans, and as foam blowing compounds (Barletta et al., 2011; McCulloch, 1999) while HFC-23 $\left(\mathrm{CHF}_{3}\right)$ is mostly a by-product of the $\mathrm{HCFC}-22\left(\mathrm{CHClF}_{2}\right)$ production (McCulloch and Lindley, 2007; Miller et al., 2010; Montzka et al., 2010; Oram et al., 1998). PFCs are emitted from aluminum smelters $\left(\mathrm{CF}_{4}\right.$, PFC-116), and are used and released in the semiconductor industry (Mühle et al., 2010). HFCs are replacing chlorinated ozone-depleting gases such as chlorofluorocarbons (CFCs) and hydrofluorochlorocarbons (HCFCs). HFC and PFC emissions are expected to have been increased in China within the last years in accordance with the high industrialization and from the substitutions of CFCs and HCFCs. Some Chinese emissions have been previously estimated based on measurements at stations downwind of China ( $\mathrm{Li}$ et al., 2011; Kim et al., 2010; Saito et al., 2010; Stohl et al., 2010; Yokouchi et al., 2006). However, only few atmospheric HFC and PFC measurements were made in China, mainly from air collected in canisters during campaigns (Barletta et al., 2006; Chan et al., 2006; Chan and Chu, 2007).

In this study, we report the first in-situ measurement of HFC-23, HFC-32 $\left(\mathrm{CH}_{2} \mathrm{~F}_{2}\right)$, HFC-134a $\left(\mathrm{CH}_{2} \mathrm{FCF}_{3}\right)$, 
HFC-152a $\left(\mathrm{CH}_{3} \mathrm{CHF}_{2}\right), \mathrm{HFC}-125\left(\mathrm{CHF}_{2} \mathrm{CF}_{3}\right), \mathrm{CF}_{4}, \mathrm{PFC}-$ $116\left(\mathrm{C}_{2} \mathrm{~F}_{6}\right)$, and PFC-218 $\left(\mathrm{C}_{3} \mathrm{~F}_{8}\right)$ at the World Meteorological Organization/Global Atmosphere Watch (WMO/GAW)'s regional background station Shangdianzi (SDZ) in northern China from May 2010 to May 2011. Mixing ratios are presented and characterized for both "background" and "polluted" conditions. Additionally, the impact of local surface horizontal advection on the observed compounds has been investigated. Chinese HFC and PFC emissions are estimated by a tracer ratio method using carbon monoxide as a reference tracer.

\section{Site description and experimental methods}

\subsection{Description of the site}

The Shangdianzi station $\left(40^{\circ} 39^{\prime} \mathrm{N}, 117^{\circ} 07^{\prime} \mathrm{E}, 291.3 \mathrm{~m}\right.$ asl $)$ is located in a mountainous area approximately $100 \mathrm{~km}$ northeast of urban Beijing in the North China Plain. SDZ is one of the atmospheric background stations run by China Meteorological Administration (CMA) and also an affiliated station of Advanced Global Atmospheric Gases Experiment (AGAGE) network. Previous studies showed that this site experienced both pollution events influenced by air masses from Beijing and other industrialized areas in the North China Plains and clean air masses from remote areas, such as Siberia, Mongolia, and the Chinese province Inner Mongolia (Lin et al., 2008; Vollmer et al., 2009; Zhang et al., 2010). The wind rose of the observation period is shown in Fig. 1. Influenced by monsoon and local valley topography, the prevailing wind sectors for the whole year are NE/ENE/E (background sectors) and SW/WSW/W (urban sectors) during the observation period, with total frequencies of approximately $40 \%$ and $32 \%$ respectively.

\subsection{Experimental methods}

Air samples are analyzed in-situ using the "Medusa" automated custom-built gas chromatographic system with mass spectrometric detection (Miller et al., 2008), with relative measurement precisions typically $<5 \%$ for HFC-32 and PFCs and $<2 \%$ for other HFCs. The system was installed in an air-conditioned container in May 2010. The sample inlet was installed at $8 \mathrm{~m}$ on a $10 \mathrm{~m}$ tower located at a distance of $30 \mathrm{~m}$ from the container, resulting in a total inlet line $<80 \mathrm{~m}$. The air is continuously drawn through a $10 \mathrm{~mm}$ OD Synflex1300 tubing by means of a membrane pump, resulting in a response time $<5 \mathrm{~min}$. The Medusa was added to the gaschromatographic measurement system that had been in operation since 2006 (Vollmer et al., 2009; Zhang et al., 2010) to add HFC and PFC measurements to the sampling program. Carbon monoxide (CO) has been measured in-situ since 2007 by a non-dispersive infrared (NDIR) method (Horiba AMPA360CE) with a resolution of $1 \mathrm{~min}$ and with a measurement precision $<10 \mathrm{ppb}$ (parts per billion, $10^{-9}$, molar). The $\mathrm{CO}$

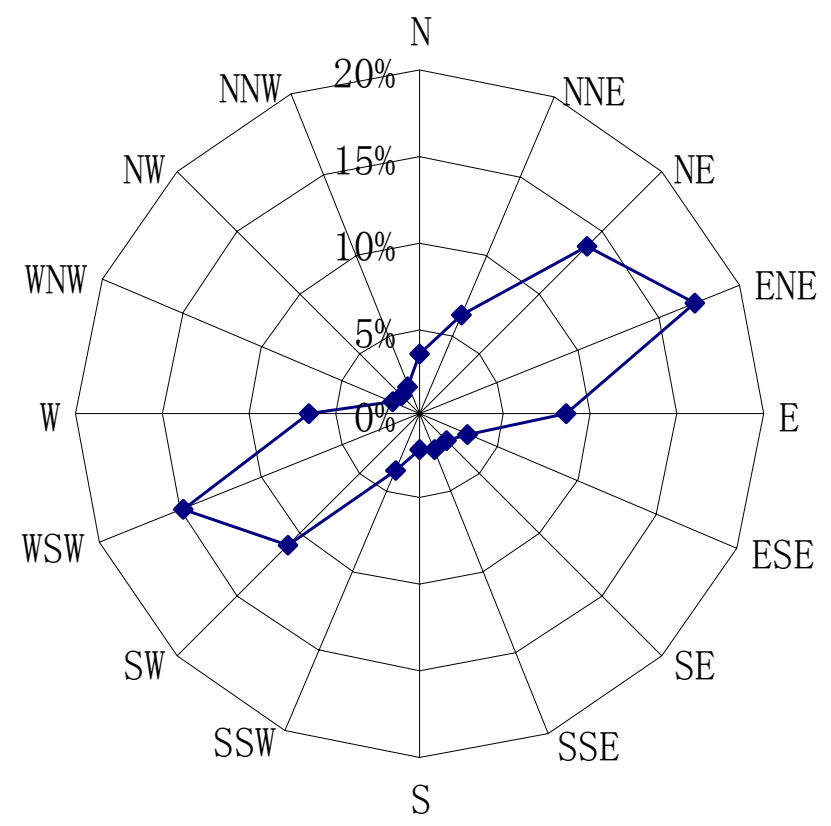

Fig. 1. Probability distribution function of local wind direction (wind rose) at the Shangdianzi station for May 2010 to May 2011 based on hourly data.

measurements are linked to the WMO-2000 calibration scale and are reported accordingly. All the instruments mentioned above share the same inlet. Horizontal surface wind data with a resolution of $1 \mathrm{~h}$ are obtained from the top of the same tower.

Each Medusa air sample measurement (every second hour) is bracketed by a reference gas (termed working standard or quaternary standard) measurement to detect and correct for drift in the detector sensitivity. Our measurements are linked to AGAGE (Prinn et al., 2000; Mühle et al., 2010), and are reported as dry air mole fractions on the calibration scales developed at the Scripps Institution of Oceanography (SIO), and the University of Bristol (UB): SIO-2005 $\left(\mathrm{CF}_{4}, \mathrm{HFC}-134 \mathrm{a}, \mathrm{HFC}-152 \mathrm{a}\right), \mathrm{SIO}-07$ (HFC-23, HFC-32, PFC-116, PFC-218), UB-98 (HFC-125).

\subsection{Baseline estimation}

For the analysis of pollution events, baseline conditions were distinguished from pollution events by applying the "robust extraction of baseline signal" filter (REBS; Ruckstuhl et al., 2012). The filter iteratively fits a local regression curve to the data using robustness weights for values above the baseline and iteratively excluding data points outside a 3.5 sigma range around the current baseline. A window width of 60 days was chosen for the REBS. This allows the baseline fit to follow relatively quick changes in baseline levels due to the change in advection from mostly northerly directions during the colder season to mostly southerly advection during the warm season. The fit converged after 5 iterations. 


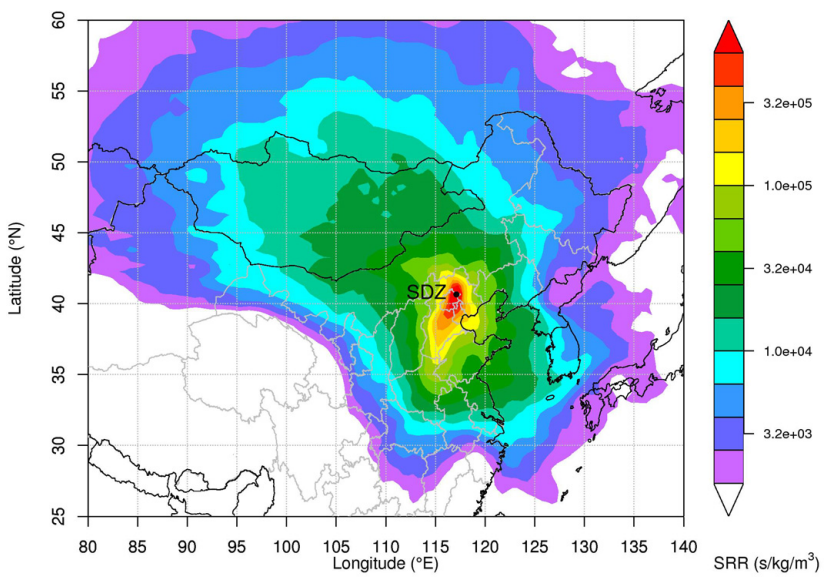

Fig. 2. Total source receptor relationship (SRR) as calculated for the Shangdianzi station for times when CO was identified to be elevated above background during the entire year of observation.

The filter was applied separately to all halocarbon and to the CO time series.

\subsection{Calculation of source receptor relationships}

To identify the area from which SDZ received significant emission contribution to the observed mole fractions, backward trajectory calculations were performed using the Lagrangian particle dispersion model FLEXPART (V9.01; Stohl et al., 2005). For each 3-hourly time interval 50000 model particles were released at the location of SDZ and traced backwards in time for 10 days. FLEXPART simulates advection by the main wind, turbulent and convective dispersion of the model particles. The model was driven by the operational analysis of the European Centre for Medium range Weather Forecast (ECMWF) with a global resolution of $1^{\circ}$ by $1^{\circ}$ and higher resolution nest of $0.2^{\circ}$ by $0.2^{\circ}$ over northeastern China.

The derived source receptor relationships (SRR) (Seibert and Frank, 2004) present a measure how sensitive the observations at SDZ are to emissions on the grid. The SRR (in $\mathrm{s} \mathrm{kg}^{-1} \mathrm{~m}^{3}$ ) for a certain time can directly be multiplied with the grid cell emissions (in $\mathrm{kg} \mathrm{s}^{-1}$ ) and divided by the grid cell volume (in $\mathrm{m}^{3}$ ) at the source to derive mass mixing ratios at the receptor. Large SRR values indicate strong sensitivities to emissions. In Fig. 2 the total SRR is shown, calculated as the sum of all SRRs during the entire year for which CO observations at SDZ were classified as pollution events.

\subsection{Emission estimation using a tracer ratio method}

The tracer ratio method (TRM) has been used for the emission estimate of halocarbons in a number of previous studies (Barletta et al., 2011; Kim et al., 2010; Li et al., 2011; Palmer et al., 2003; Reimann et al., 2004; Saito et al., 2010; Shao et al., 2011; Yokouchi et al., 2006). The method is based on the assumption that the target halocarbon and the chosen tracer behave similar in the atmosphere and thus their emission ratio is conserved during the transport from the source to the receptor. The increase of the tracers above their baseline concentrations as observed at any receptor can then be used to estimate the tracer ratio and consequently the emissions of a target tracer if the emissions of the reference tracer are known with a sufficient degree of certainty. The method requires that there are no significant atmospheric loss or production processes of the tracers during the period of transport. Furthermore, the method is supposed to work best if emission sources of different tracers are collocated and temporal emission profiles are similar. The distance between emission sources and receptor will also influence the applicability of the method in that it determines the degree of atmospheric mixing (spatial integration) from different emission sources. Receptors that are located relatively close to the sources may observe relatively well defined ratios from more specific sources (source areas) because atmospheric turbulence did not yet disperse and mix individual signals. Receptors at larger distances may observe larger spread in ratios, since signals from different sources were mixed within the atmosphere prior to arrival at the site. Hence such sites may be more suitable to up-scale emission estimates to larger areas and the collocation requirement may be relaxed. For remote receptors the definition of above baseline signals becomes more and more challenging because the atmospheric mixing (integration) dilutes the original emission ratio and observed pollution peaks may not significantly differ from the baseline. These requirements and limitations should be kept in mind when interpreting the emission estimates as derived with the TRM.

In this study, we chose $\mathrm{CO}$ as the reference tracer because most of the observed HFCs and PFCs were statistically significantly $(p<0.01)$ correlated with in-situ CO measurements, showing Pearson correlation coefficients larger than 0.45 (see Fig. 3). The correlation was not significant for HFC-134a $(r=0.26)$. The use of CO as reference tracer is in contrast to recent studies by Kim et al. (2010), Li et al. (2011) and Saito et al. (2010) who used HCFC-22 as a reference tracer. However, in the case of SDZ the correlations of HCFC-22 with the observed HFCs and PFCs were less consistent as for $\mathrm{CO}$ (Pearson correlation coefficient larger 0.5 for HFC-134a and not significantly different from 0 for HFC-23, HFC-152a, PFC-116 and PFC-218). Using CO as a reference tracer has the advantage that $\mathrm{CO}$ emissions from China were extensively studied in the recent past (Ohara et al., 2007; Streets et al., 2003; Zhang et al., 2009) and are relatively well known. One disadvantage of using $\mathrm{CO}$ as a reference tracer may be that its emissions may be less well collocated with halocarbon emissions, owing to the fact that $\mathrm{CO}$ emissions do not only result from the same processes as halocarbon emissions but may, for example, be caused by residential use of coal and biofuels in more rural areas of China. The fraction of residential $\mathrm{CO}$ emissions was estimated by 


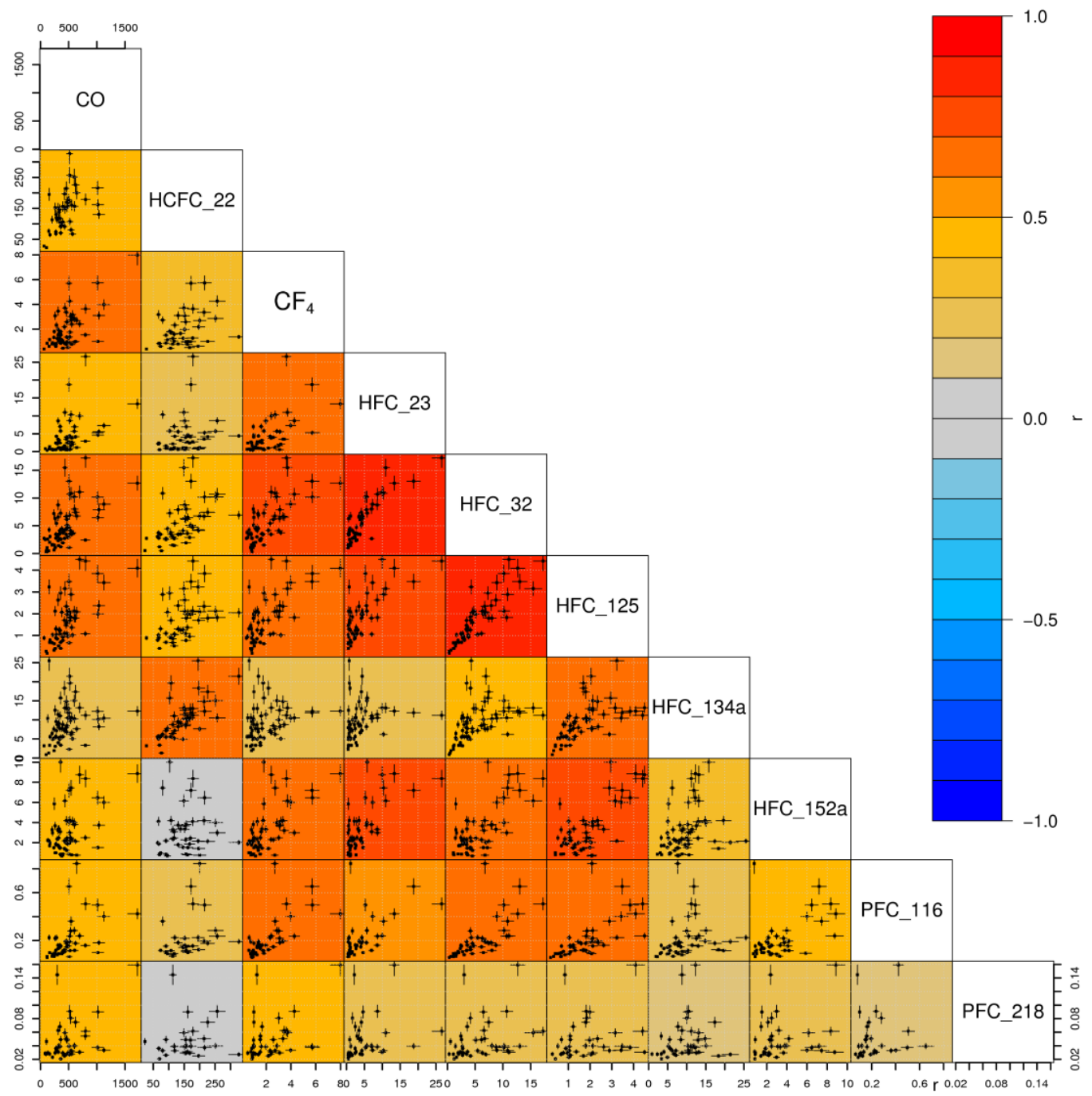

Fig. 3. Correlation plot matrix between observed $\mathrm{CO}$ and halocarbon mole fractions. Individual scatter plots show 5-day aggregates of above baseline data. The background color refers to the Pearson correlation coefficient $r$, positive correlation is indicated by red colors, negative correlation by blue colors. Mole fractions are given in units ppt for all halocarbons and ppb for CO.

Zhang et al. (2009) and the EDGAR global emission inventory (http://edgar.jrc.ec.europa.eu/) to be about a third of the Chinese total emissions. This fraction is considerably larger than that for the USA (6\%, EDGAR V4.2) but similar to that of European countries (France $21 \%$, Germany $29 \%$, Italy $22 \%$ ) for which $\mathrm{CO}$ was successfully used as a reference tracer for emission estimation of halogenated greenhouse gases (Reimann et al., 2004). In contrast to European $\mathrm{CO}$ emissions, Chinese $\mathrm{CO}$ emissions undergo a rather pronounced annual cycle as shown by Streets et al. (2003). This may lead to a larger spread in the observed tracer ratio and an increased uncertainty in halocarbon emission estimates. A further limitation of using $\mathrm{CO}$ as a reference tracer is the fact that $\mathrm{CO}$ is both consumed (oxidation by hydroxyl radicals) and produced (from oxidation of methane and other volatile organic compounds) in the atmosphere. However, consider- ing the relatively short transport times (days) from the major emissions sources in North-East China towards SDZ and CO lifetimes in the order of weeks this presents a minor source of error.

Finally, the emissions of the target halocarbon $E_{x}\left[\mathrm{kt} \mathrm{yr}^{-1}\right]$ can be calculated from its mixing ratio enhancement over baseline conditions $\left(\Delta \mathrm{C}_{x}\right)$ and the mixing ratio enhancement of $\mathrm{CO}(\triangle \mathrm{CO})$ by:

$E_{x}=E_{\mathrm{CO}} b \frac{M_{x}}{M_{\mathrm{CO}}}$, with $b=\frac{\Delta C_{x}}{\Delta C_{\mathrm{CO}}}$

Here $E_{\mathrm{CO}}$ is the total emission of $\mathrm{CO}, M_{\mathrm{CO}}$ is its molecular weight, and $M_{x}$ is the molecular weight of the target halocarbon. The uncertainty of the emission estimate is given by error propagation. 
$\sigma_{E_{x}}=E_{x} \sqrt{\left(\frac{\sigma_{b}}{b}\right)^{2}+\left(\frac{\sigma_{E_{\mathrm{CO}}}}{E_{\mathrm{CO}}}\right)^{2}}$

Total Chinese $\mathrm{CO}$ emissions during the observation period were estimated to $193.3 \mathrm{Mt} \mathrm{yr}^{-1}$ using the estimate by Zhang et al. (2009) of $166.9 \mathrm{Mt} \mathrm{yr}^{-1}$ for 2006 and a growth rate of $3.4 \% \mathrm{yr}^{-1}$, assuming that the growth rate for 2006 to 2011 remains the same as the one reported by Zhang et al. (2009) for 2001 to 2006. The uncertainty of the total Chinese CO emissions was estimated by Zhang et al. (2009) to $\pm 35 \%$ (1$\sigma)$. Assuming an uncertainty of the growth rate of $\pm 100 \%$ we estimate the uncertainty for the period of investigation to be $\pm 37.8 \%$.

The observations at SDZ may not be representative for the whole of China. The area influencing SDZ during pollution events covered most of the densely-populated North China Plains, and also extends towards southern parts of China such as Yangtz river region. Sensitivities towards Korea were relatively small and were neglected during further analysis. The site would have been sensitive to emissions from Mongolia. However, these were considered to be relatively small and were not further considered. The total $\mathrm{CO}$ emissions from the provinces to which SDZ is most sensitive (green areas: Anhui, Beijing, Hebei, Henan, Jiangsu, Jilin, Liaoning, Inner Mongolia, Shandong, Shanxi, Tianjin) were $88 \mathrm{Mt} \mathrm{yr}^{-1}$ in 2006 (Zhang et al., 2009) and assuming the same country-wide growth rate as above $102 \mathrm{Mt} \mathrm{yr}^{-1}$ in 2010/2011. In a first step, we estimate the emissions for the mentioned Provinces (called North China Plains in the following) using the stated uncertainty of $\pm 37.8 \%$, while in a second step total Chinese emissions were extrapolated using an additional uncertainty of $10 \%$ to account for representativeness uncertainties.

The tracer ratio $b$ has been calculated with different methods in the past. While some authors estimate it as the ratio between the average enhancement over the baseline (e.g., Reimann et al., 2004), others have calculated the median of the ratio from different pollution events (e.g., Li et al., 2011), and yet others have used regression analysis, fitting a straight line to the data (Shao et al., 2011). Here the tracer ratio $b$ and its uncertainty was estimated using the weighted total least square (WTLS) regression of a straight line with uncertainties in both coordinates (Krystek and Anton, 2007). This procedure assures that the calculated slope is invariant to the selection of the parameter on the $\mathrm{x}$ - and $\mathrm{y}$-axis, which is not guaranteed when using the ordinary least square regression. Furthermore, in contrast to the orthogonal distance regression used by Shao et al. (2011), the WTLS regression allows for proper weighting of uncertainties in both variables, which is important in the case of different average uncertainties between parameters, and also for individual data points with increased uncertainty.
Prior to the regression analysis "above baseline" mixing ratios were aggregated to 5-day averages to remove autocorrelation in the data. Aggregates were only kept for further analysis if at least 3 valid "above baseline" values were present within the aggregation interval. Without this data aggregation the calculated uncertainties of $b$ would be underestimated, because the regression assumes independent uncertainties of the input data, which is not the case for autocorrelated time series. The uncertainties of the 5-day aggregates were governed by non-random uncertainties (accuracy) due to calibration scale and propagation uncertainty, while the aggregation diminishes the random part (precision) of the uncertainty. Combined uncertainties of the aggregates were $3 \%$ for $\mathrm{CO}$ and $5 \%$ for the HFCs and PFCs with the exception of HFC-23 were, due to smaller precision, the uncertainties were $10 \%$.

As an alternative estimate of the tracer ratio $b\left(b_{\mathrm{r}}\right.$ in the following), we calculated the median of the ratio of all 5-day aggregates (called direct ratio calculation in the following), while the median absolute deviation was used as an estimator of the uncertainty of $b_{\mathrm{r}}$.

\section{Results and discussion}

\subsection{Time series and background data selection}

One-year time series for HFC and PFC mixing ratios from 6 May 2010 to 5 May 2011 are shown in Fig. 4 (data gaps were due to instrument malfunction). For most HFCs and $\mathrm{CF}_{4}$, mixing ratios at SDZ show large episodic events, with elevated concentrations from polluted air masses most likely arriving from urban areas. Furthermore, 1 month of measurements is shown for HFC-125 and CO to show the concurrent behavior of the two substances.

Using the pollution filter, $36 \%$ (HFC-32) to $83 \%$ (PFC218) of all valid measurements have been selected as background data (Table 1). Pollution-classified mixing ratios (grey dots) exhibit large fluctuations compared to the background measurements. The mean mixing ratio difference between pollution and background can be attributed to recent emissions. Of all compounds measured, HFC-134a has the greatest mixing ratio difference between pollution and background. Compared to HFCs, pollution events for the PFCs are less frequent and smaller in size, with the exception of $\mathrm{CF}_{4}$.

\subsection{Comparison of background mixing ratio and trends}

Since the HFC and PFC working standards at SDZ are traceable to the standards scale of the AGAGE network, the data are directly comparable to results from the AGAGE stations. Here we compare our results to the following four AGAGE stations: Jungfraujoch, Mace Head, Trinidad Head, and Cape Grim. The geographic information of these 4 stations is listed in Table 2. Cape Grim, located in the Southern Hemisphere 
Table 1. Data analysis for hydrofluorocarbons (HFCs) and perfluorocarbons (PFCs) measured at Shangdianzi for 6 May $2010-5$ May 2011. The data were separated into background air and polluted air using a statistical filter, and the statistics shown applies to each of the two separate data sets.

\begin{tabular}{lcccccccc}
\hline Compounds & No. of air samples & $\begin{array}{c}\text { Percentage } \\
\text { of background }\end{array}$ & \multicolumn{2}{c}{$\begin{array}{c}\text { Background mixing } \\
\text { ratio (ppt) }\end{array}$} & \multicolumn{3}{c}{$\begin{array}{c}\text { Pollution mixing } \\
\text { ratio (ppt) }\end{array}$} \\
\cline { 4 - 8 } & & & Mean & S.D. & Mean & S.D. & $10 \%$ & $90 \%$ \\
\hline HFC-23 & 3438 & $48.2 \%$ & 24.5 & 0.33 & 28.8 & 5.77 & 25.0 & 35.3 \\
HFC-32 & 3444 & $36.0 \%$ & 5.86 & 0.38 & 10.7 & 6.27 & 6.23 & 17.8 \\
HFC-125 & 3414 & $39.9 \%$ & 9.97 & 0.44 & 11.4 & 1.68 & 9.98 & 13.8 \\
HFC-134a & 3399 & $36.3 \%$ & 66.0 & 1.20 & 74.4 & 8.92 & 67.0 & 84.1 \\
HFC-152a & 3390 & $52.9 \%$ & 9.77 & 0.55 & 13.1 & 3.37 & 10.4 & 17.6 \\
CF & 3376 & $48.2 \%$ & 79.1 & 0.23 & 81.2 & 2.21 & 79.5 & 83.9 \\
PFC-116 & 3312 & $59.5 \%$ & 4.22 & 0.04 & 4.45 & 0.19 & 4.30 & 4.70 \\
PFC-218 & 2318 & $83.0 \%$ & 0.56 & 0.02 & 0.62 & 0.06 & 0.59 & 0.67 \\
\hline
\end{tabular}

(SH), is used here as representative for $\mathrm{SH}$ air. The other three station, are located at similar latitudes compared to SDZ in the Northern Hemisphere (NH).

The background mixing ratios for most HFCs and PFCs at SDZ are consistent with those obtained at other NH stations (see Table 2). The differences for the background HFCs mixing ratios between SDZ and Trinidad Head, which are almost located at the same latitude, are within $2.9 \%$ for all compounds listed in Table 2 .

There are differences for the background mixing ratios of HFCs and PFCs up to several ppt (parts per trillion, $10^{-12}$, molar) between SDZ and Cape Grim, especially for HFC134a and HFC-152a. These larger differences are expected as they are typically observed for all long-lived gases emitted in substantial quantities from human activities. Of all the compounds listed in Table 2, HFC-152a shows the biggest relative difference of all stations, due to its shortest lifetime of all measured compound.

There is no recent report on HFC-32 NH background levels. Global background mixing ratios are reported as 2.7 ppt for 2008 (WMO Ozone Assessment report 2011: see Montzka et al., 2011). Assuming that the growth rate re-

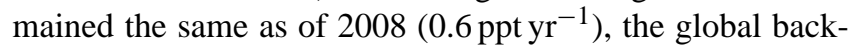
ground mixing ratio from May 2010 to May 2011 is calculated as $4.2 \mathrm{ppt}$ which is smaller than in our study at SDZ. The difference (1.7 ppt) might due to the difference between NH and SH, or bigger growth rate of HFC-32 since 2008.

The annual mean growth rates of HFC-32, HFC-134a, and HFC-125 are calculated by linear curve fitting for the compounds with $R^{2}>0.7$. Figure 5 presents HFC-32 and HFC125 as examples. For HFC-23, HFC-152a, and three PFCs, annual mean growths are obtained from monthly mixing ratio means difference between May 2010 (6 May to 31 May) and May 2011 (1 May to 31 May) because the linear cure fitting for them were with poor $R$.

Both HFCs and PFCs exhibit positive trends at rates of $0.7 \pm 0.2,1.4 \pm 0.05,1.6 \pm 0.03,4.1 \pm 0.15,1.1 \pm 0.3$,
$0.43 \pm 0.20,0.05 \pm 0.04,0.01 \pm 0.01 \mathrm{ppt} \mathrm{yr}^{-1}$ for HFC-23, HFC-32, HFC-125, HFC-134a, HFC-152a, CF 4 , PFC-116, and PFC-218, respectively. HFCs show higher trends than PFCs. Of all the compounds, HFC-134a shows the biggest yearly grow rate up to $4.1 \mathrm{ppt} \mathrm{yr}^{-1}$ while the grow rates of other HFCs are approximately $1 \mathrm{ppt} \mathrm{yr}^{-1}$. For the PFCs, the background mixing ratios of $\mathrm{CF}_{4}$ increased $0.43 \mathrm{ppt} \mathrm{yr}^{-1}$, while the other 2 PFCs increased by less than $0.1 \mathrm{ppt} \mathrm{yr}^{-1}$. Compared to their background mixing ratios, HFC-23, HFC32, HFC-125, HFC-134a, HFC-152a, CF 4 , PFC-116, and PFC-218 increased by $2.9 \%, 24 \%, 16 \%, 6.2 \%, 11 \%, 0.5 \%$, $1.2 \%, 1.8 \%$ per year, respectively. HFCs also show higher relative trends compared to PFCs, of which HFC-32 shows the biggest relative trend.

\subsection{Impact of local surface horizontal winds on the observed HFCs and PFCs}

The combination of in-situ measurements with meteorological data can improve the understanding of the relationship between enhanced concentrations and emissions (Dlugokencky et al., 1993; Zhou et al., 2004). In this study, the impacts of local winds on atmospheric HFC and PFC mixing ratios were investigated based on one year of observations. Synchronous hourly surface wind data were calculated based on meteorological measurement from SDZ. The surface wind data was calculated based on the sampling time of the in-situ measurement and was then separated into 16 wind directions.

Mixing ratio anomalies (differences between mixing ratios in each wind sector and their means) and loadings (mixing ratio anomalies weighted by time $(8760 \mathrm{~h})$ associated with winds in a given sector) were calculated based on the method described in the previous studies (Zhang et al., 2010; Zhou et al., 2003, 2004). Both anomalies and loadings are performed on the full set of measurements. Figure 6 displays statistical anomalies and loadings of the HFCs and PFCs from the 16 wind sectors. 

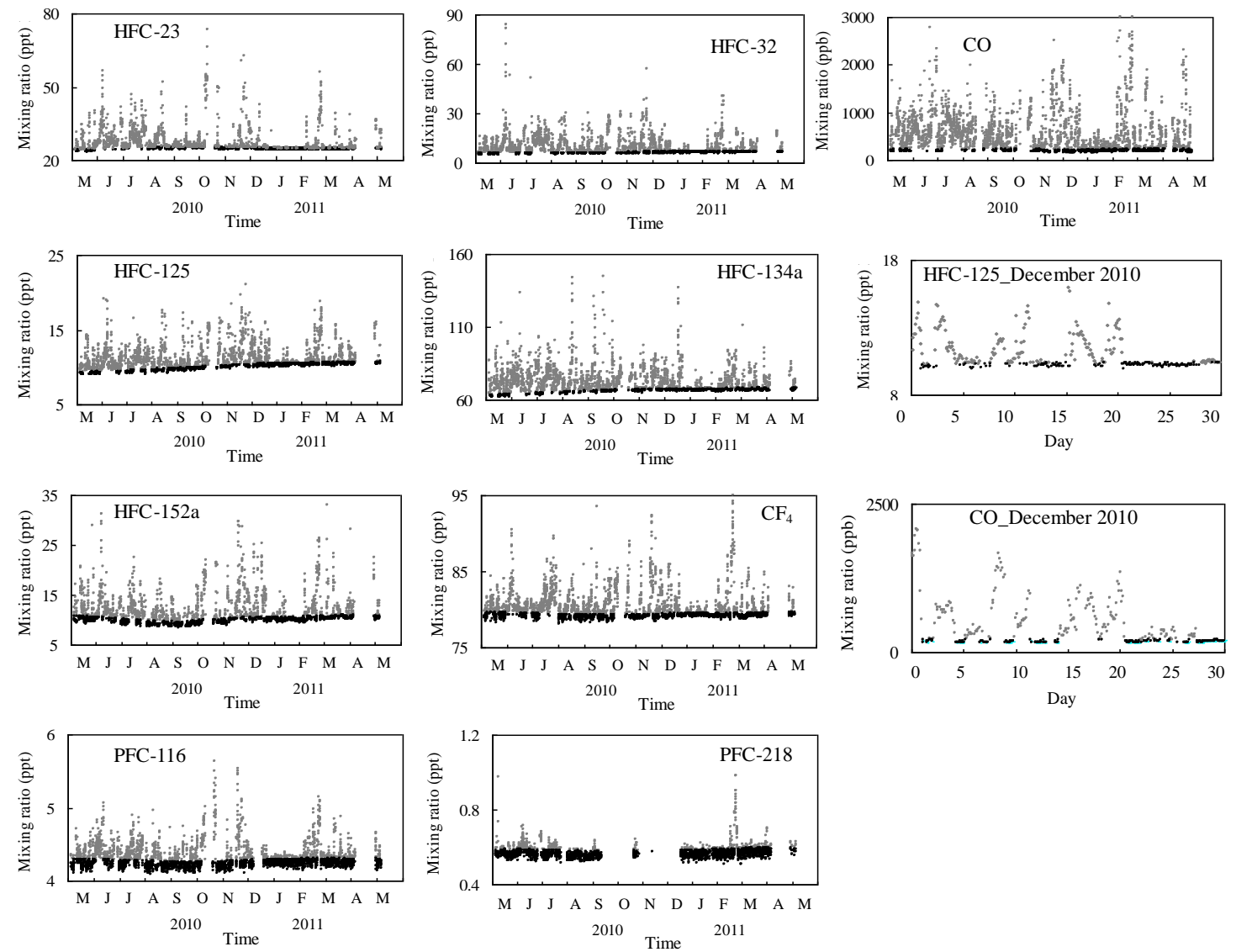

Fig. 4. Time series of HFCs, PFCs and CO at the Shangdianzi station during May 2010 to May 2011. The two panels in the middle right show detailed examples of one month records of CO and HFC-125, grey dots for polluted data and black dots for background data.

Table 2. Comparison of background mixing ratios at Shangdianzi (SDZ, given 1- $\sigma$ uncertainty) and four AGAGE stations during the observation period (mixing ratios are given in $\mathrm{ppt}$ ).

\begin{tabular}{lrrrrr}
\hline Compounds & SDZ & Jungfraujoch & Mace Head & Trinidad Head & Cape Grim \\
\hline Longitude & $117.12^{\circ} \mathrm{E}$ & $7.99^{\circ} \mathrm{E}$ & $9.90^{\circ} \mathrm{W}$ & $124.15^{\circ} \mathrm{W}$ & $144.68^{\circ} \mathrm{E}$ \\
Latitude & $40.65^{\circ} \mathrm{N}$ & $46.55^{\circ} \mathrm{N}$ & $53.33^{\circ} \mathrm{N}$ & $41.05^{\circ} \mathrm{N}$ & $40.68^{\circ} \mathrm{S}$ \\
Altitude & $293 \mathrm{~m}$ & $3580 \mathrm{~m}$ & $8 \mathrm{~m}$ & $120 \mathrm{~m}$ & $94 \mathrm{~m}$ \\
\hline HFC-23 & $24.5 \pm 0.33$ & 24.0 & 24.0 & 23.9 & 22.9 \\
HFC-125 & $9.97 \pm 0.44$ & 9.96 & 9.77 & 9.69 & 7.77 \\
HFC-134a & $66.0 \pm 1.20$ & 66.6 & 65.3 & 65.0 & 54.8 \\
HFC-152a & $9.77 \pm 0.55$ & 9.57 & 9.70 & 9.56 & 4.08 \\
$\mathrm{CF}_{4}$ & $79.1 \pm 0.23$ & 79.0 & 79.0 & 79.0 & 78.0 \\
PFC-116 & $4.22 \pm 0.04$ & 4.15 & 4.18 & 4.19 & 4.05 \\
PFC-218 & $0.56 \pm 0.02$ & 0.55 & 0.56 & 0.55 & 0.53 \\
\hline
\end{tabular}

Data for Mace Head, Trinidad Head and Cape Grim are provided by AGAGE, in particular from the institutions responsible for these three stations: the University of Bristol, Scripps Institution of Oceanography (SIO) and the Commonwealth Scientific and Industrial Research Organisation (CSIRO). 

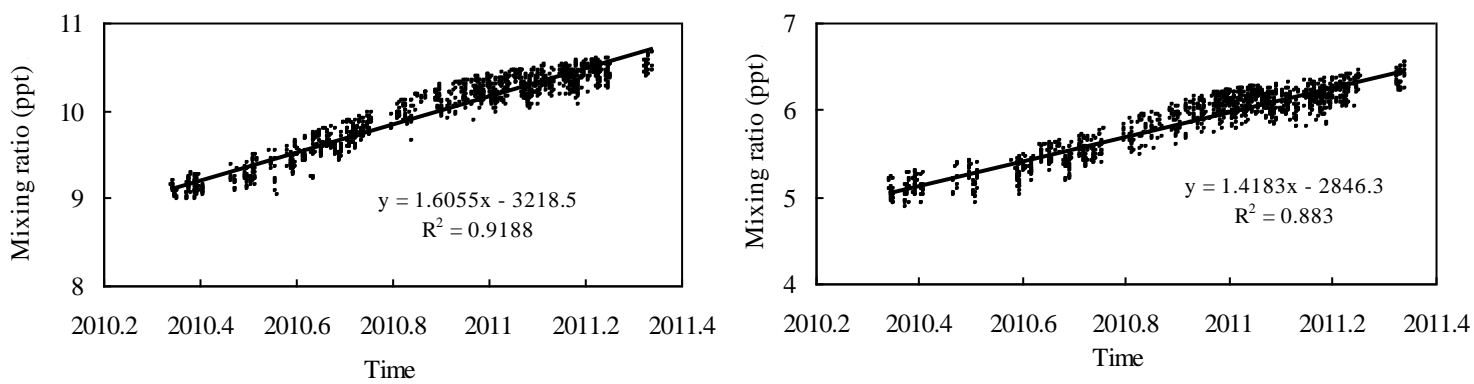

Fig. 5. Annual trends of HFC-125 (left) and HFC-32 (right) at the Shangdianzi station.
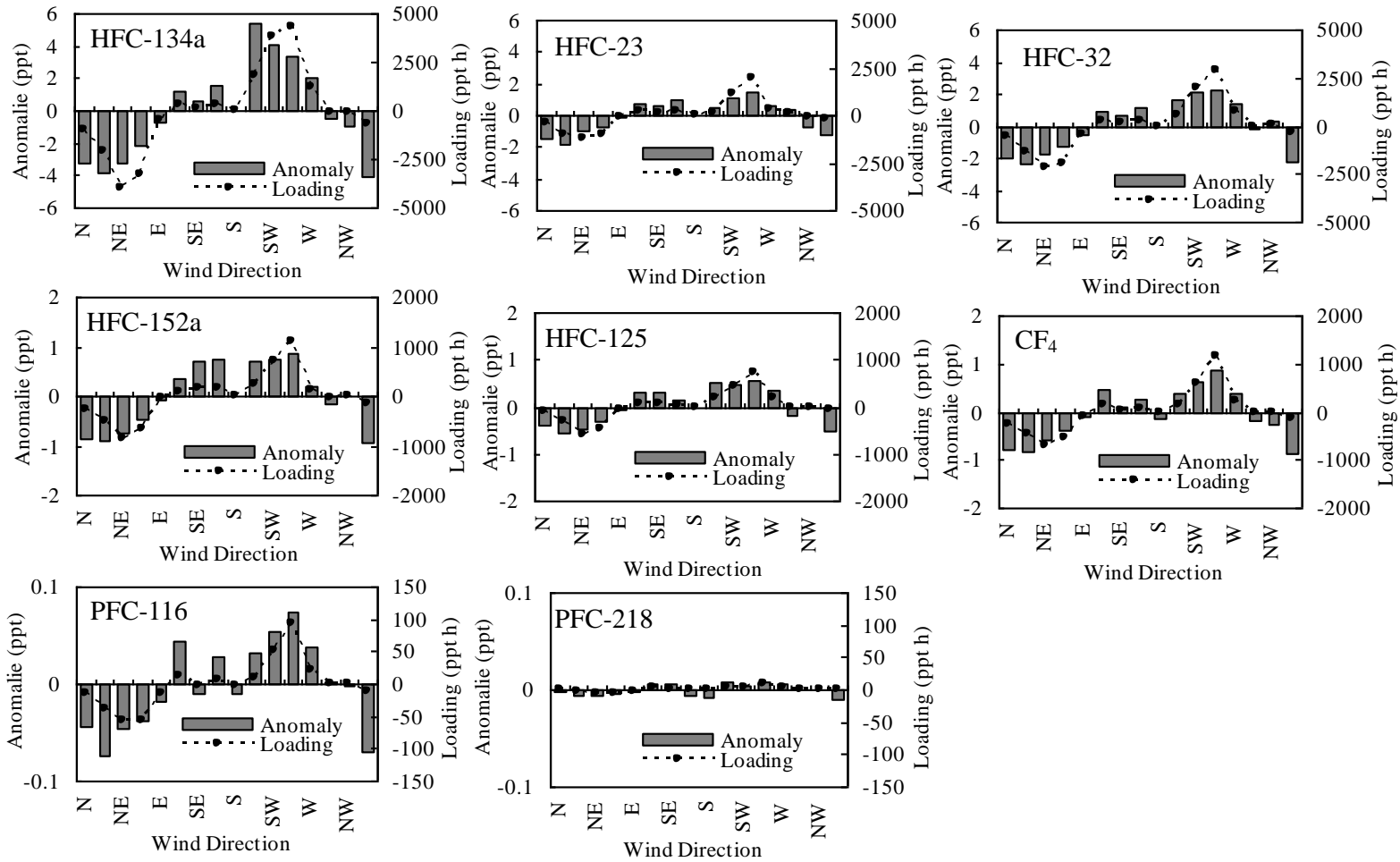

Fig. 6. Statistical anomalies mean mixing ratios for each wind sector and loadings for different wind sectors at the Shangdianzi station from May 2010 to May 2011.

For PFC-218, anomalies for all wind directions are within $\pm 0.01 \mathrm{ppt}$ indicating that there are no distinct emission sources in the region influencing SDZ. For other compounds, the mixing ratios are most enhanced from WSW and SW, which are the directions towards downtown Beijing. These two sectors also contribute most to loadings. Winds originating from the northeast sector always exhibited negative mixing ratio anomalies as concentrations are lowest during times of air mass origins from N/NNE/NNW. However, the wind frequencies of these sectors are relatively small so that their loadings do not contribute much. The biggest negative loadings are in sectors NE/ENE which have almost same amounts as position contribution of SW/WSW.
Of all HFCs and PFCs, the mixing ratio of HFC-134a is most enhanced (> 5pt) in SSW/SW/WSW and loading for SW/WSW is approximately $4000 \mathrm{ppth}$. For other HFCs and $\mathrm{CF}_{4}$, the maximal anomalies and loading are around $0.5 \sim 2$. ppt and $700 \sim 2900 \mathrm{ppth}$, while for PFC-116, the maximal anomalies and loading are less than $0.1 \mathrm{ppt}$ and 120 ppth.

\subsection{Emission estimates by the tracer ratio method}

The results of the regression analysis of all halocarbons versus $\mathrm{CO}$ are shown in Fig. 7.

The estimated HFC-23 emissions (see Table 3) were $1.9 \pm 1.7 \mathrm{kt} \mathrm{yr}^{-1}$ and $1.4 \pm 1.1 \mathrm{kt} \mathrm{yr}^{-1}$ for the North China 

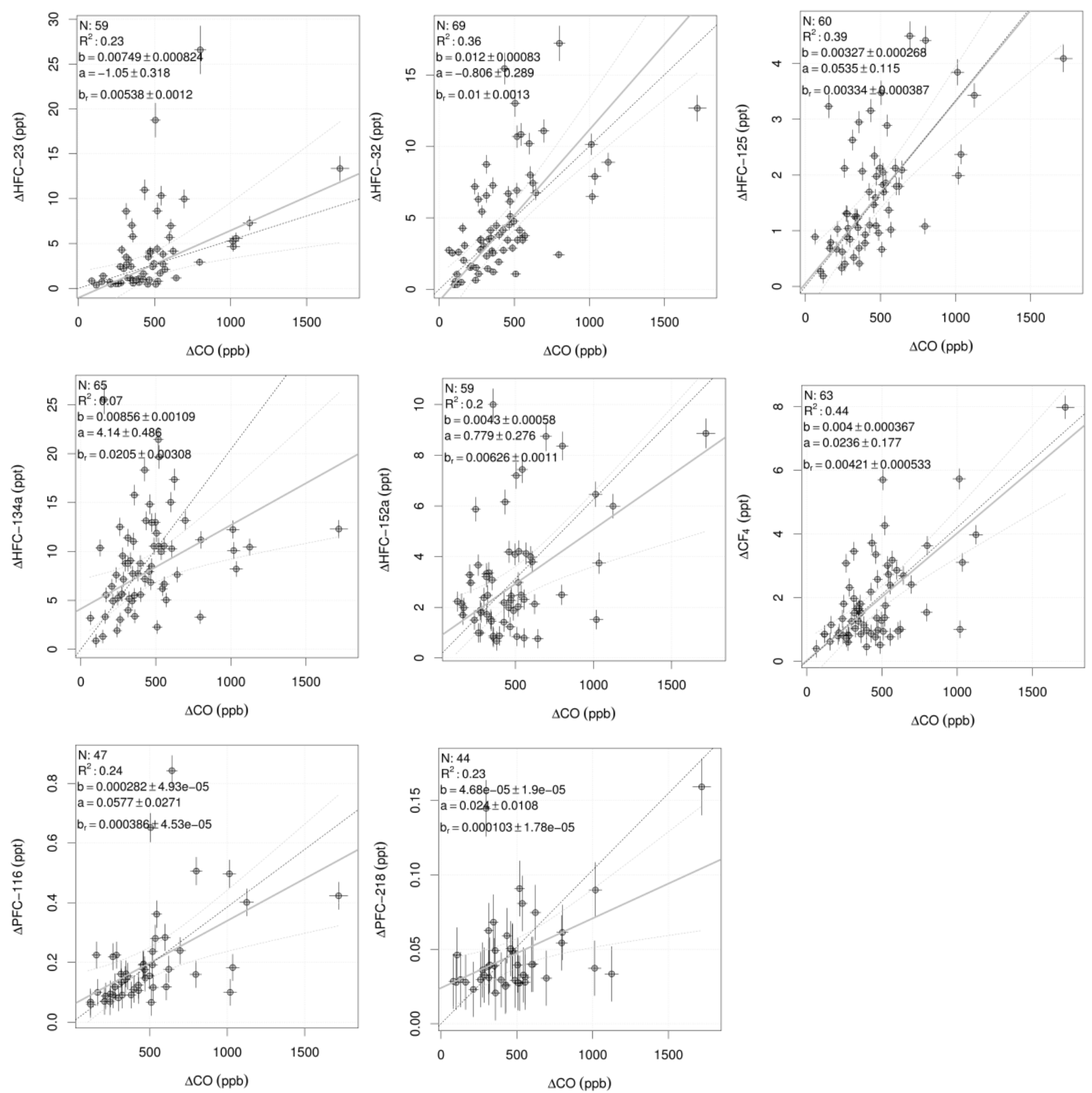

Fig. 7. Regression plots of 5-day above baseline aggregates (symbols) of observed halocarbon mole fractions versus CO mole fractions. The error bars on the individual 5-day aggregates give the 1- $\sigma$ uncertainty. The result of the WTLS regression (parameters $a$ and $b$ ) is given by the grey solid line and its $95 \%$ confidence band by the grey dashed line. The result of the median tracer ratio $\left(b_{\mathrm{r}}\right)$ is indicated by the black solid line.

Plains and $3.6 \pm 3.2 \mathrm{ktyr}^{-1}$ and $2.6 \pm 2.1$ for the whole of China by regression analysis and by direct ratio calculation of TRM. Our emission estimate for HFC-23 is much smaller than that for 2004 by Yokouchi et al. (2006) $\left(10 \pm 4.6 \mathrm{kt} \mathrm{yr}^{-1}\right)$. Considering that HFC-23 is mainly a byproduct in the HCFC-22 production, these reductions could be explained by the fact that some Chinese companies have executed the Clean Development Mechanism (CDM) since 2005, which may have resulted in reduced HFC-23 emissions. Based on the data reported by the United Nations Framework Convention on Climate Change (UNFCCC, http://cdm.unfccc.int), the achieved reductions in emission 
Table 3. Emission estimates for hydrofluorocarbons (HFCs) and perfluorocabons (PFCs) for the North China Plain and the whole of China. Results are given for the two methods to estimate the tracer ratio b: weighted total least square (WTLS) regression analysis (Regression) and median of direct ratio calculation (Ratio). All numbers are given in $\mathrm{kt} \mathrm{yr}^{-1}$. The uncertainty estimates represent the $95 \%$ confidence limits. The emission estimates for HFC-134a may be questionable due to insignificant correlation between $\mathrm{CO}$ and HFC-134a so its estimates are given braces.

\begin{tabular}{lrr|rr}
\hline \multirow{2}{*}{ Compound } & \multicolumn{2}{c|}{ North China Plain } & \multicolumn{2}{c}{ China } \\
\cline { 2 - 5 } & Regression & Ratio & Regression & Ratio \\
\hline HFC-23 & $1.9 \pm 1.7$ & $1.4 \pm 1.1$ & $3.6 \pm 3.2$ & $2.6 \pm 2.1$ \\
HFC-32 & $2.3 \pm 1.8$ & $1.9 \pm 1.5$ & $4.3 \pm 3.6$ & $3.6 \pm 2.9$ \\
HFC-125 & $1.4 \pm 1.2$ & $1.5 \pm 1.1$ & $2.7 \pm 2.3$ & $2.8 \pm 2.2$ \\
HFC-134a & $(3.2 \pm 2.9)$ & $(7.6 \pm 5.9)$ & $(6.0 \pm 5.6)$ & $(14 \pm 11)$ \\
HFC-152a & $1.0 \pm 0.9$ & $1.5 \pm 1.2$ & $2.0 \pm 1.8$ & $2.9 \pm 2.3$ \\
CF & $1.3 \pm 1.1$ & $1.4 \pm 1.0$ & $2.4 \pm 2.1$ & $2.6 \pm 2.0$ \\
PFC-116 & $0.14 \pm 0.14$ & $0.19 \pm 0.15$ & $0.27 \pm 0.26$ & $0.37 \pm 0.29$ \\
PFC-218 & $0.032 \pm 0.050$ & $0.071 \pm 0.055$ & $0.061 \pm 0.095$ & $0.134 \pm 0.107$ \\
\hline
\end{tabular}

were $\sim 5.6 \mathrm{kt} \mathrm{yr}^{-1}$ because of the CDM projects executed by eleven Chinese chemical factories in 2010. This is approximately the difference between the emission estimates by this study and by Yokouchi et al. (2006) for 2004. An investigation of factories involved in CDM projects found these factories had more reduced emissions than those they reported to UNFCCC (http://cdm.unfccc.int/), it may partly be compensated by the increase in HCFC-22 production of recent years (Wan, 2010). Top-down emission estimates by Stohl et al. (2010) for 2008 also found Chinese HFC-23 emissions reduced compared to the EDGAR bottom up emissions for 2005. Miller et al. (2010) found that HFC-23 global emissions decreased from $15.0 \mathrm{kt} \mathrm{yr}^{-1}$ for 2005 to $8.6 \mathrm{kt} \mathrm{yr}^{-1}$ for 2009 mainly due to CDM projects executed in developing countries. The bottom-up estimate by Wan (2010) also shows that Chinese HFC-23 emissions decreased from $9.4 \mathrm{kt} \mathrm{yr}^{-1}$ (2005) to $\sim 7 \mathrm{kt} \mathrm{yr}^{-1}$ (2008). Due to the release of HFC23 at a few point sources the collocation requirement with $\mathrm{CO}$ emissions may be less well fulfilled for HFC-23 than for other HFCs and PFCs. However, the correlation coefficient between $\mathrm{CO}$ and HFC-23 was not smaller than for a number of other HFCs/PFCs. This might be explained by the fact that none of the HCFC-22 producing factories is close to SDZ and HFC-23 emissions from these point sources will be mixed with regional scale $\mathrm{CO}$ emissions on their way to SDZ. HCFC-22 factories are distributed throughout the whole of China. Although individual production numbers are not known to us, it is possible to deduce that about half of these factories are situated within the area from which SDZ receives emissions. This is similar to our estimate concerning total versus regional $\mathrm{CO}$ emissions. Therefore, no strong bias of our HFC-23 emissions estimate due to the geographical location of the factories is expected.

HFC-32, HFC-125 and HFC-152a are mainly used as foam blowing agents, aerosol propellants, and in refriger- ation mixtures (Velders et al., 2009). Emissions of HFC32 , HFC-125, HFC-152a were $4.3 \pm 3.6,2.7 \pm 2.3$ and $2.0 \pm 1.8 \mathrm{kt} \mathrm{yr}^{-1}$, respectively, for the whole China by regression analysis of TRM and the differences between emissions estimated by two methods were within $32 \%$ for the three HFCs. Our estimates agree with previous studies (Kim et al., 2010; Stohl et al., 2010) considering the uncertainties (see Table 4).

The correlation coefficient of HFC-134a and $\mathrm{CO}$ was not significantly different from 0 . The intercept estimated by the regression was significantly different from 0 , suggesting that the assumption of collocated $\mathrm{CO}$ and HFC134a emission does not hold well in this case and our HFC-134a emission estimates should carefully be interpreted. The estimated HFC-134a emissions (see Table 3) differ strongly between the two estimates of the tracer ratio $3.2 \pm 2.9 \mathrm{kt} \mathrm{yr}^{-1}$ and $7.6 \pm 5.9 \mathrm{kt} \mathrm{yr}^{-1}$ for the North China Plains and $6.0 \pm 5.6 \mathrm{kt} \mathrm{yr}^{-1}$ and $14 \pm 11 \mathrm{kt} \mathrm{yr}^{-1}$ for the whole of China. Compared to the other parameters and considering the weak correlation our uncertainty estimate of HFC-134a emissions seems to be too small. Of all HFCs, HFC-134a has the largest emission. Two thirds of the produced HFC134a was used for mobile air conditioners to replace CFC12 since 2001 (Wan, 2010). With the rapid increase of the Chinese automobile industry and the phasing out of CFC-12, Chinese HFC-134a emission probably will be continuously increasing. Bottom-up emission estimate based on difference assumption varies from $13.6 \mathrm{kt} \mathrm{yr}^{-1}$ to $21.1 \mathrm{kt} \mathrm{yr}^{-1}$ for 2010 with a growth rate of $30 \% \mathrm{yr}^{-1}$ (Hu et al., 2009; Wan, 2010).

The correlation coefficients of three PFCs and CO were significantly different from 0 and the intercepts estimated by the regression were not significantly different from 0 of $\mathrm{CF}_{4}$ and PFC-116. However, for PFC-218, the intercept estimated by the regression was not significantly different from 0 and the estimated emissions differ strongly between the two estimates of TRM (see Table 3). Emission estimates for $\mathrm{CF}_{4}$, PFC-116, and PFC-218 were $2.4 \pm 2.1,0.27 \pm 0.26$, and $0.061 \pm 0.095 \mathrm{kt} \mathrm{yr}^{-1}$ for the whole of China by regression analysis. PFC-116 emission is approximately half of the emission estimated by Saito et al. (2010) and Kim et al. (2010) for 2008 and close to EDGAR report for 2008 $\left(0.263 \mathrm{kt} \mathrm{yr}^{-1}\right)$. For $\mathrm{CF}_{4}$ and PFC-218, there are small differences between our estimates and other studies considering the respective uncertainties.

\section{Conclusions}

Based on the 1-yr measurements at Shangdianzi, we observe similar baseline levels compared to those AGAGE stations at similar latitudes, and positive trends were found for HFC23, HFC-32, HFC-125, HFC-134a, HFC-152a, $\mathrm{CF}_{4}$, PFC116, and PFC-218. Compared to a previous study (Yokouchi et al., 2006), HFC-134a had replaced HFC-23 with largest emission of HFCs in China. This is likely to become more 
Table 4. Chinese emission estimates for hydrofluorocarbons (HFCs) and perfluorocarbons (PFCs). Uncertainty estimates for this study represent the $95 \%$ confidence limits. Numbers from this study refer to the results obtained with the regression method. The emission estimates for HFC-134a may be questionable due to insignificant correlation between CO and HFC-134a so its estimates are given braces.

\begin{tabular}{lrrrrrr}
\hline \multirow{2}{*}{ Compound } & \multicolumn{7}{c}{ Emission estimate $\mathrm{kt} \mathrm{yr}^{-1}$} \\
\cline { 2 - 7 } & This study & $\begin{array}{r}\text { Stohl et al. } \\
(2010)\end{array}$ & $\begin{array}{r}\text { Saito et al. } \\
(2010)\end{array}$ & $\begin{array}{r}\text { Kim et al. } \\
(2010)\end{array}$ & $\begin{array}{r}\text { Yokouchi et al. } \\
(2006)\end{array}$ & $\begin{array}{r}\text { EDGAR V4.2 } \\
(2012)\end{array}$ \\
\hline Period & $5.2010-5.2011$ & 2008 & $2006-2009$ & 2008 & 2004 & 2008 \\
\hline HFC-23 & $3.6 \pm 3.2$ & $6.2 \pm 0.7$ & & $12(8.6-15)$ & $10 \pm 4.6$ & 13.0 \\
HFC-32 & $4.3 \pm 3.6$ & & $4.3(3.2-5.9)$ & & 0 \\
HFC-125 & $2.7 \pm 2.3$ & & $3.2(2.4-4.4)$ & $3.9 \pm 2.4$ & 0 \\
HFC-134a & $(6.0 \pm 5.6)$ & $12.9 \pm 1.7$ & & $8.7(6.5-12)$ & & 1.01 \\
HFC-152a & $2.0 \pm 1.8$ & $3.4 \pm 0.5$ & & $5.7(4.3-7.6)$ & $4.3 \pm 2.3$ & 0 \\
CF4 & $2.4 \pm 2.1$ & & & $2.3(1.7-3.1)$ & & 1.70 \\
PFC-116 & $0.27 \pm 0.26$ & & $0.57(0.36-0.90)$ & $0.49(0.37-0.66)$ & & 0.263 \\
PFC-218 & $0.061 \pm 0.095$ & & $0.08(0-0.17)$ & $0.09(0.07-0.12)$ & & 0.00073 \\
\hline
\end{tabular}

Emission of China mainland from EDGAR V4.2: http://edgar.jrc.ec.europa.eu/overview.php?v=42.

pronounced with the execution of CMD projects as well as the rapid increase of China's automobile industry (using HFC-134a as air conditioning fluid). Our emission estimates using the $\mathrm{CO}$ ratio method are tagged with considerable uncertainties due to limited spatial and temporal coverage. A network with more stations, especially observations from south China, would improve spatial resolution and reduce the uncertainties in the emission estimates.

Acknowledgements. This work was supported by the National Nature Science Foundation of China (41030107), National Basic Research Program of China "973" (Grant No. 2010CB950601), MOST EU S and T Cooperative Project (1015), the Sino-Swiss Science and Technology Cooperation project 2SMONG, SOGG-EA of the Research Council of Norway and CMA operation funding. The station personnel and the Beijing Meteorological Bureau have extensively supported the operation at Shangdianzi. Peter Salameh from Scripps Institution of Oceanography (SIO) is acknowledged for his help with the data acquisition and processing software. Christina Harth helped to calibrate the tertiary tanks for SDZ. Jens Mühle helped to update the GC-MS system and optimize daily maintenance. This work has benefited from technical assistance by the AGAGE networks. We thank SIO, the University of Bristol and the Commonwealth Scientific and Industrial Research Organisation (CSIRO) for providing some unpublished data of Trinidad Head, Mace Head and Cape Grim station.

Edited by: C. Reeves

\section{References}

Barletta, B., Meinardi, S., Simpson, I. J., Rowland, F. S., Chan, C.Y., Wang, X., Zou, S., Chan, L. Y., and Blake, D. R.: Ambient halocarbon mixing ratios in 45 Chinese cities, Atmos. Environ., 40, 7706-7719, doi:10.1016/j.atmosenv.2006.08.039, 2006.

Barletta, B., Nissenson, P., Meinardi, S., Dabdub, D., Sherwood Rowland, F., VanCuren, R. A., Pederson, J., Diskin, G. S., and Blake, D. R.: HFC-152a and HFC-134a emission estimates and characterization of CFCs, CFC replacements, and other halogenated solvents measured during the 2008 ARCTAS campaign (CARB phase) over the South Coast Air Basin of California, Atmos. Chem. Phys., 11, 2655-2669, doi:10.5194/acp-11-26552011, 2011.

Chan, L. Y. and Chu, K. W.: Halocarbons in the atmosphere of the industrial-related Pearl River Delta region of China, J. Geophys. Res., 112, D04305, doi:10.1029/2006JD007097, 2007.

Chan, C. Y., Tang, J. H., Li, Y. S., and Chan, L. Y.: Mixing ratios and sources of halocarbons in urban, semi-urban and rural sites of the Pearl River Delta, South China, Atmos. Environ., 40, 7331-7345, doi:10.1016/j.atmosenv.2006.06.041, 2006.

Dlugokencky, E. J., Harris, J. M., Chung, Y. S., Tans, P. P., and Fung, I.: The relationship between the methane seasonal cycle and regional sources and sinks at Tae-ahn Peninsula, Korea, Atmos. Environ, Part A: Gen. Top., 27, 2115-2120, doi:10.1016/09601686(93)90041-V, 1993.

Hu, J., Wan, D., Li, C., Zhang, J., and Yi, X.: Forecasting of consumption and emission of HFC-134a used in automobile air conditioner sector in China, Adv. Clim. Change Res., 5, 1-6, 2009.

IPCC: Climate Change 2007: The physical science basis. Contribution of working group I to the fourth assessment report of the intergovernmental panel on climate change. Cambridge University Press, Cambridge, United Kingdom and New York, NY, USA, 2007.

Li, S., Kim, J., Kim, K.-R., Mühle, J., Kim, S.-K., Park, M.-K., Stohl, A., Kang, D.-J., Arnold, T., Harth, C. M., Salameh, P. K., and Weiss, R. F.: Emissions of halogenated compounds in East Asia determined from measurements at Jeju Island, Korea, Environ. Sci. Technol., 45, 5668-5675, 2011. 
Lin, W., Xu, X., Zhang, X., and Tang, J.: Contributions of pollutants from North China Plain to surface ozone at the Shangdianzi GAW Station, Atmos. Chem. Phys., 8, 5889-5898, doi:10.5194/acp-8-5889-2008, 2008.

Kim, J., Li, S., Kim, K.-R., Stohl, A., Mühle, J., Kim, S.-K., Park, M.-K, Kang, D.-J., Lee, G., Harth, C. M., Salameh, P. K., and Weiss, R. F.: Regional atmospheric emissions determined from measurements at Jeju Island, Korea: Halogenated compounds from China, Geophys. Res. Lett., 37, L12801, doi:10.1029/2010GL043263, 2010.

Krystek, M. and Anton, M.: A weighted total least-squares algorithm for fitting a straight line, Meas. Sci. Tech., 18, 3438-3442, 2007.

McCulloch, A.: CFC and Halon replacements in the environment, J. Fluorine Chem., 100, 163-173, 1999.

McCulloch, A. and Lindley, A. A.: Global emissions of HFC23 estimated to year 2015, Atmos. Environ., 41, 1560-1566, doi:10.1016/j.atmosenv.2006.02.021, 2007.

Miller, B. R., Weiss, R. F., Salameh, P. K., Tanhua, T., Greally, B. R., Mühle, J., and Simmonds, P. G.: Medusa: A sample preconcentration and GC/MS detector system for in situ measurements of atmospheric trace halocarbons, hydrocarbons, and sulfur compounds, Anal. Chem., 80, 1536-1545, doi:10.1021/ac702084k, 2008.

Miller, B. R., Rigby, M., Kuijpers, L. J. M., Krummel, P. B., Steele, L. P., Leist, M., Fraser, P. J., McCulloch, A., Harth, C., Salameh, P., Mühle, J., Weiss, R. F., Prinn, R. G., Wang, R. H. J., O'Doherty, S., Greally, B. R., and Simmonds, P. G.: HFC$23\left(\mathrm{CHF}_{3}\right)$ emission trend response to $\mathrm{HCFC}-22\left(\mathrm{CHClF}_{2}\right)$ production and recent HFC-23 emission abatement measures, Atmos. Chem. Phys., 10, 7875-7890, doi:10.5194/acp-10-78752010, 2010.

Montzka, S. A., Kuijpers, L., Battle, M. O., Aydin, M., Verhulst, K. R., Saltzman, E. S., and Fahey, D. W.: Recent increases in global HFC-23 emissions, Geophys. Res. Lett., 37, L02808, doi:10.1029/2009GL041195, 2010.

Montzka, S. A., Reimann, S., Engel, A., Krüger, K., O’Doherty, S., Sturges, W. T., Blake, D., Dorf, M., Fraser, P., Froidevaux, L., Jucks, K., Kreher, K., Kurylo, M. J., Mellouki, A., Miller, J., Nielsen, O.J., Orkin, V. L., Prinn, R. G., Rhew, R., Santee, M. L., Stohl, A., and Verdonik, D.: Ozone-depleting substances (ODSs) and related chemicals. In Scientific Assessment in Ozone Depletion: 2010, Chapter 1, Global Ozone Research and Monitoring Project-Report No. 52, World Meteorological Organization: Geneva, Switzerland, 2011.

Mühle, J., Ganesan, A. L., Miller, B. R., Salameh, P. K., Harth, C. M., Greally, B. R., Rigby, M., Porter, L. W., Steele, L. P., Trudinger, C. M., Krummel, P. B., O’Doherty, S., Fraser, P. J., Simmonds, P. G., Prinn, R. G., and Weiss, R. F.: Perfluorocarbons in the global atmosphere: tetrafluoromethane, hexafluoroethane, and octafluoropropane, Atmos. Chem. Phys., 10, 5145-5164, doi:10.5194/acp-10-5145-2010, 2010.

Ohara, T., Akimoto, H., Kurokawa, J., Horii, N., Yamaji, K., Yan, X., and Hayasaka, T.: An Asian emission inventory of anthropogenic emission sources for the period 1980-2020, Atmos. Chem. Phys., 7, 4419-4444, doi:10.5194/acp-7-4419-2007, 2007.

Oram, D. E., Sturges, W. T., Penkett, S. A., McCulloch, A., and Fraser, P. J.: Growth of fluoroform $\left(\mathrm{CHF}_{3}, \mathrm{HFC}-23\right)$ in the back- ground atmosphere, Geophys. Res. Lett., 25, 35-38, 1998.

Palmer, P. I., Jacob, D. J., Mickley, L. J., Blake, D. R., Sachse, G. W., Fuelberg, H. E., and Kiley, C. M.: Eastern Asian emission of anthropogenic halocarbons deduced from aircraft concentration data, J. Geophys. Res., 108, 4573, doi:10.1029/2003JD003591, 2003.

Prinn, R. G., Weiss, R. F., Fraser, P. J., Simmonds, P. G., Cunnold, D. M., Alyea, F. N., O’Doherty, S., Salameh, P., Miller, B. R., Huang, J., Wang, R. H. J., Hartley, D. E., Harth, C., Steele, L. P., Sturrock, G., Midgley, P. M., and McCulloch, A.: A history of chemically and radiatively important gases in air deduced from ALE/GAGE/AGAGE, J. Geophys. Res., 105, 1775117792, doi:10.1029/2000JD900141, 2000.

Reimann, S., Schaub, D., Stemmler, K., Folini, D., Hill, M., Hofer, P., and Buchmann B.: Halogenated greenhouse gases at the Swiss high Alpine site of Jungfraujoch (3580 m asl): Continuous measurements and their use for regional European source allocation, J. Geophys. Res., 109, D05307, doi:10.1029/2003JD003923, 2004.

Ruckstuhl, A. F., Henne, S., Reimann, S., Steinbacher, M., Vollmer, M. K., O’Doherty, S., Buchmann, B., and Hueglin, C.: Robust extraction of baseline signal of atmospheric trace species using local regression, Atmos. Meas. Tech., 5, 2613-2624, doi:10.5194/amt-5-2613-2012, 2012.

Saito, T., Yokouchi, Y., Stohl, A., Taguchi, S., and Mukai, H.: Large emissions of perfluorocarbons in East Asia deduced from continuous atmospheric measurements, Environ. Sci. Technol., 44, 4089-4095, 2010.

Seibert, P. and Frank, A.: Source-receptor matrix calculation with a Lagrangian particle dispersion model in backward mode, Atmos. Chem. Phys., 4, 51-63, doi:10.5194/acp-4-51-2004, 2004.

Shao, M., Huang, D., Gu, D., Lu, S., Chang, C., and Wang, J.: Estimate of anthropogenic halocarbon emission based on measured ratio relative to $\mathrm{CO}$ in the Pearl River Delta region, China, Atmos. Chem. Phys., 11, 5011-5025, doi:10.5194/acp-11-50112011, 2011.

Stohl, A., Forster, C., Frank, A., Seibert, P., and Wotawa, G.: Technical note: The Lagrangian particle dispersion model FLEXPART version 6.2, Atmos. Chem. Phys., 5, 2461-2474, doi:10.5194/acp-5-2461-2005, 2005.

Stohl, A., Kim, J., Li, S., O’Doherty, S., Mühle, J., Salameh, P. K., Saito, T., Vollmer, M. K., Wan, D., Weiss, R. F., Yao, B., Yokouchi, Y., and Zhou, L. X.: Hydrochlorofluorocarbon and hydrofluorocarbon emissions in East Asia determined by inverse modeling, Atmos. Chem. Phys., 10, 35453560, doi:10.5194/acp-10-3545-2010, 2010.

Streets, D. G., Bond, T. C., Carmichael, G. R., Fernandes, S. D., Fu, Q., He, D., Klimont, Z., Nelson, S. M., Tsai, N. Y., Wang, M. Q., Woo, J.-H., and Yarber, K. F.: An inventory of gaseous and primary aerosol emissions in Asia in the year 2000, J. Geophys. Res., 108, 8809, doi:10.1029/2002JD003093, 2003.

Velders, G. J. M., Fahey, D. W., Daniel, J. S., McFarland, M., and Andersen, S. O.: The large contribution of projected HFC emissions to future climate forcing, Proc. Natl. Acad. Sci. USA, 106, 10949-10954, doi:10.1073/pnas.0902817106, 2009.

Vollmer, M. K., Zhou, L. X., Greally, B. R. Henne, S., Yao, B., Reimann, S., Stordal, F., Cunnold, D. M., Zhang, X. C., Maione, M., Zhang, F., Huang, J., and Simmonds, P. G.: Emissions of ozone-depleting halocarbons from China, Geophys. Res. Lett., 
36, L15823, doi:10.1029/2009GL038659, 2009.

Wan, D.: Establishment and Verification of Emissions Inventories of Major ODS and HFCs in China. Doctoral Dissertation, Peking University, China, 2010 (in Chinese with English abstract).

Yokouchi, Y., Taguchi, S., Saito, T., Tohjima, Y., Tanimoto, H., and Mukai, H.: High frequency measurements of HFCs at a remote site in east Asia and their implications for Chinese emissions, Geophys. Res. Lett., 33, L21814, doi:10.1029/2006GL026403, 2006.

Zhang, Q., Streets, D. G., Carmichael, G. R., He, K. B., Huo, H., Kannari, A., Klimont, Z., Park, I. S., Reddy, S., Fu, J. S., Chen, D., Duan, L., Lei, Y., Wang, L. T., and Yao, Z. L.: Asian emissions in 2006 for the NASA INTEX-B mission, Atmos. Chem. Phys., 9, 5131-5153, doi:10.5194/acp-9-5131-2009, 2009.
Zhang, F., Zhou, L., Yao, B., Vollmer, M. K., Greally, B. R., Simmonds, P.G., Reimann, S., Stordal, F., Maione, M., Xu, L., and Zhang, X.: Analysis of 3-year observations of CFC-11, CFC-12 and CFC-113 from a semi-rural site in China, Atmos. Environ., 44, 4454-4462, doi:10.1016/j.atmosenv.2010.07.041, 2010.

Zhou, L., Tang, J., Wen, Y., Li, J., Yan, P., and Zhang, X.: The impact of local winds and long-range transport on the continuous carbon dioxide record at Mount Waliguan, China, Tellus, 55B, 145-158, doi:10.1034/j.1600-0889.2003.00064.x, 2003.

Zhou, L. X., Worthy, D. E. J., Lang, P. M., Ernst, M. K., Zhang, X. C., Wen, Y. P., and Li, J. L.: Ten years of atmospheric methane observations at a high elevation site in Western China, Atmos. Environ., 38, 7041-7054, doi:10.1016/j.atmosenv.2004.02.072, 2004. 